\title{
Artists of Their Time: The Postwar Battle for Realism in Literature and Painting
}

\section{Alice Ferrebe}

From the establishment of the Committee for the Encouragement of Music and the Arts (CEMA) in 1940, cultural regeneration was anticipated as a vital part of the reconstruction of Britain. The means of achieving this rejuvenation, however, remained conflicted once the Second World War was over. Although innovation was, as ever, an artistic priority, the pull of pre-war class and aesthetic certainties was also strong: to Norman Mackenzie, postwar Britain was in a 'stalemate state, that curious interval in our social history, in which there was no way back to the world which had gutted out into war yet no clear way forward to a really new society'.1

Before the war began, Georg Lukács had attempted to move the debate around art's social contract beyond the presiding battle-lines. Its terms, he claimed in a 1938 essay, 'are not classics versus modernists; discussion must focus instead on the question: which are the progressive trends in the literature of today?' He added: 'It is the fate of realism that hangs in the balance.'2 In the postwar discussions focused upon British literature, a binary (and frequently nostalgic) logic prevailed in the

\footnotetext{
${ }^{1}$ Norman Mackenzie, 'After the Stalemate State' in Norman Mackenzie (ed.), Conviction (London: MacGibbon \& Kee, 1958), p. 7.

${ }^{2}$ Georg Lukács, 'Realism in the Balance' in Theodore Adorno, Walter Benjamin, Ernst Bloch et al., Aesthetics and Politics (Radical Thinkers) (London: Verso, 1980), p. 30 .
} 
conceptualisation of potentially 'progressive trends'. This was predicated upon a presiding confrontation of modernism versus realism, with the latter, broadly, in cultural ascendancy. In the journal Our Time in 1947, E. P. Thompson cast modernism as 'the ideological defence of a dying civilization', and by 1953, C. P. Snow was ringing its knell in the Sunday Times, claiming modernism had now 'died from starvation because its intake of human stuff was so low' ${ }^{3}$ Encounter magazine, which began in 1953, strove to reimagine modernism in a Cold War context, as pro-freedom, pro-individualism and pro-Western - even pro-bourgeois - and set it against an inescapably Socialist realism of communally circumscribed ambitions and dogmatic form. Even this determined project, however, was characterised by a curious resignation to modernism's contemporary death: Greg Barnhisel notes that 'a melancholy and self-aware belatedness, a wistful resignation, colors Encounter's modernism'. ${ }^{4}$ Stephen Spender's editorial to the magazine's third edition begins by summoning what he calls 'substantial ghosts, feeding life', the first of which is individualism. 5

In other of the arts, the moribund realist/modernist binary that so dominated debates in British writing was complicated and animated. Through its various aesthetic and ethical positions around, in particular, abstraction and figuration, postwar British painting, although also engaged in what art historian James Hyman has called a 'Battle for Realism', offers a potentially more complex field of political and artistic debate than

3 E. P. Thompson, 'Comments on a People's Culture', Our Time (October 1947), p. 38; C. P. Snow, 'New Trends in First Novels', Sunday Times (27 December 1953), p. 3. ${ }^{4}$ Greg Barnhisel, 'Encounter Magazine and the Twilight of Modernism' (2014) 81(1) ELH408.

5 Stephen Spender, 'Editorial: Ghosts of a Renascence', Encounter 1.3 (December 1953), p. 2. 
that provided by literary criticism.6 A diverse selection of fiction writers recognised this potential, and made use of ekphrasis, the verbal representation of visual art, to explore their aesthetic and political anxieties over established modes of realism. Although still susceptible to caricature, particularly in relation to the binary politics of the Cold War, painting's philosophies and practices provide an instructive means of refracting, refiguring and reflecting upon the artistic challenges faced by postwar novelists.

Joyce Cary's novel The Horse's Mouth, its diegesis spanning the beginning of the Second World War, was published in 1944. Its painter protagonist Gulley Jimson is the son of an artist who met with considerable success in an earlier era ('landscape with figures. Girls in gardens') before being driven out of the Academy to make room for the pre-Raphaelites.7 Jimson thus inherits an acute awareness of the accelerating revolutions of the cycle of artistic fashion: 'All art is bad', as he puts it jovially, 'but modern art is the worst'. ${ }^{8}$ His own recent work draws considerable condemnation. 'Look at the awful disgusting pictures Jimson paints', he parrots his critics, 'look at that Adam and Eve - worse than Epstein or Spencer ... A shocking thing. Thank God Jimson's papa never saw it'.9

To be 'worse than Epstein', in Jimson's contrary pantheon, is an achievement indeed. Cary considered the sculptor to epitomise the original artist: 'he does something to you, and you can't overlook or forget it'.10 For Jimson, this barrage of criticism and denigrating comparison merely evidences his engagement in the proper role of art as a

${ }^{6}$ James Hyman, The Battle for Realism: Figurative Art in Britain During the Cold War, 1945-1960 (New Haven, CT: Yale University Press, 2001).

${ }^{7}$ Joyce Cary, The Horse's Mouth (Harmondsworth: Penguin, 1948), p. 23.

8 Ibid., p. 24.

9 Ibid., p. 25.

10 Joyce Cary, 'On Jacob Epstein', unpublished essay, quoted in Alan Bishop, Gentleman Rider: A Biography of Joyce Cary (London: Michael Joseph, 1988), p. 311. 
constant process of repainting and renewal. Just as he cheerfully accepts that the mural he counts as his finest work lies beneath four coats of whitewash in a village hall in Devon, so he extols the virtues of classical art to season canvases for his own use: 'There's nothing like a real old Master for an undercoating.'11 Unsurprisingly, in the light of his patrimony, Jimson recalls how the portrait of himself as an artist began, before the turn of the twentieth century, with an undercoat: 'I started as a Classic. About 1800 was my period ... I had a picture in the old Water Colour Society that year. Very classical. Early Turner. Almost Sandby.'12 Jimson's younger self, then, aspired to be an Old Master, or at least a new classicist: Paul Sandby was the only founder member of the Royal Academy to work in water-colour, and is routinely cited as being the father of English landscape painting.

This penchant for water-colours may seem like a harmless admission of the conservatism of youth. Yet to Jimson's understanding it has more sinister associations. Talking politics at the pub, Jimson claims the Second World War has just started '[b]ecause of modern art ... Hitler never could put up with modern art. It's against his convictions. His game was water-colour in the old coloured-water style.

Topographical'.13 The affiliation between modernism, formal experimentation and fascist sympathies that lingered in literary criticism (despite Encounter's best efforts) has fewer biographical precedents in relation to visual art. Instead, Kenneth Clark was to claim, 'totalitarian art must be a form of classicism: the state which is founded on order or subordination demands an art with a similar basis'.14 Jimson's revulsion stems

11 Cary, The Horse's Mouth, pp. 170, 142.

12 Ibid., p. 70.

13 Ibid., p. 357.

14 Kenneth Clark, The Romantic Rebellion: Romantic versus Classical Art (London: Harper \& Row, 1973), p. 32. 
in part from an awareness that he is not himself immune to fascistic tendencies in his personal life. When his anarchist friend Plantie commends artists for giving their lives to their art, Jimson responds ruefully, mindful of the cost of his own artistic commitments paid by the women who have loved him: 'And other people's lives ... Like Hitler.'15

Lady Beeder, wife of the 'old Lord' Beeder, Jimson's potential patron, is herself a producer of water-colours 'in the traditional style'.16 Despite these underlying oldfashioned tastes, the 'Boorjwas' Beeders invest their money in the 'Usual modern collection' ${ }^{17}$ Comically catalogued by Jimson, this ranges across styles from 'Wilson Steer, water in watercolour' to 'Epstein, Leah waiting for Jacob in squawtacolour'.18 Because of its commercially recognised value, much of this art is worthless to him. The Beeders attempt to commission one of Jimson's nudes, the only mode of his work that garners any financial value in the current market, and one he has cast off as outdated. When they go on holiday, Jimson sets about transforming their well-appointed domestic exhibition space into a combination of bohemian studio and doss-house, working on a 'raising of Lazarus' on the wall of their dining room, and sleeping on a pile of newspapers in the corner.

'Through cash to culture' is Jimson's cheerful motto, and his exuberant destruction of the Beeders' home is his demonstration of the inescapable elements of exploitation in any relationship of artistic patronage. ${ }^{19}$ However, Jimson does make it clear that the support of artists should ultimately fall to a society's government. Asked

15 Cary, The Horse's Mouth, p. 82.

16 Ibid., p. 179.

17 Ibid., p. 274.

18 Ibid., p. 178.

19 Ibid., p. 180. 
what would happen if there were no millionaires to patronise art, Jimson invokes a culture in which:

'The people go on with the old stuff, and folk art and so on, until they get sick.' 'Sick of art?' 'Sick of everything. Though they don't know it. It's a kind of foot-and-mouth disease. The mouth gets very foul and the feet turn sideways, so that the patient is always going round to the pub, the same pub, of course. I'm told by experts that there's a lot of it in country districts where you only have old Masters to look at. Young chaps kind of waste away.'20

Predictably, Jimson is in 'the pub, the same pub' when he makes this pronouncement, but his point is a sober one. Though ‘[y]ou can't expect a government to know what original art is', institutional faith in (and funding for) artists potentially to produce originality, is, to his mind, an investment in the nation's well-being. ${ }^{21}$

The health of the nation's culture took a prominent place among the panoply of national concerns in the postwar period. CEMA shared in an emerging consensual commitment to a stronger democracy of opportunity with regard to matters of education and welfare, both material and spiritual. Its chair since 1941, John Maynard Keynes, died shortly before the Arts Council charter was drafted in 1946, but his political influence was crucial in securing the new organisation's relatively high levels of funding amid the competing demands of reconstruction. Culture, then, formed part of the aggregate demand of foundational Keynesian economics. As Keynes explained in a broadcast at the end of the war, CEMA (like its successor, originally at least) 'was intended to support both excellence in the arts and the widest possible access to

20 Ibid., p. 306.

21 Ibid., p. 181. 
them'.22 The Labour Government elected in 1945 empowered local authorities to tax sixpence on the pound to fund cultural activities: a scheme Arthur Marwick has identified as 'culture as a form of social welfare'. ${ }^{23}$ The drive towards the democratisation of art - as well as that of health and education - speaks of the postwar consensus to be mindful of what C. P. Snow called the 'human stuff' within political systems; of the individual within societal statistics. ${ }^{24}$ Lolie, a long-suffering muse-model, puts it more viscerally in The Horse's Mouth: 'What is there to bite on in the abstract?'25

As the postwar period progresses through the 1950s, this social mission for culture has often been critically understood to manifest, in literature in particular, in dogmatic allegiance to realist practice. Yet in the case of Jimson, before and during the war, Cary works to attenuate any such straightforward links between politics and aesthetic style. His protagonist is a garrulous man, who paints with words as well as with oils: this forms a key part of the novel's ekphrastic technique. Jimson's circumlocutory, frequently contradictory, first-person narration melds visions of Blakean romanticism - 'Long flat clouds like copper angels with brass hair floating on the curls of the fire'26 - with transfigured realist mundanities: 'the allotments were in their April state, a bit bare except for regiments of bean sticks and rows of tool-houses like drunken paupers staggering about in the mud'.27 The most - perhaps the only -

22 Randall Stephenson, The Oxford English Literary History, vol. 12: 1960-2000: The Last of England (Oxford University Press, 2004), p. 33.

23 Arthur Marwick, Culture in Britain since 1945 (London: Blackwell, 1991), p. 70.

24 Snow, 'New Trends in First Novels', p. 3.

25 Cary, The Horse's Mouth, p. 259.

26 Ibid., p. 304.

27 Ibid., p. 219. 
reliable tenet of Jimson's stylistic practice is that it is invariably figurative: he shares Lolie's instinctive rejection of the abstract.

In placing his faith in Blake, Jimson is anticipating postwar cultural mores. The Arts Council's exhibition of British art that formed part of the 1951 Festival of Britain included 'The Tempera Paintings of William Blake', a collection the artist had gathered himself in 1809. Unusually, these works demonstrated Blake's desire to work on a scale aspired to by Jimson, and by postwar art more generally.28 As painter John Bratby was later to claim of the period: 'The scale was important. This was an obsession. Paintings had to be large. It was one of those strange things that happened. A reaction against the small picture.'29 The size of his work aside, Susan Matthews has noted the inspirational potential of Blake, as a simultaneously dissenting yet Christian cultural figure, to provide a rejuvenating postwar model for spiritual belief outside established religious structures. ${ }^{30}$ Envisioning how to repaint the Adam of his 'Fall' painting, Jimson claims his inspiration to come 'straight from the horse': whether this is God or Blake is not revealed, and does not in effect matter. ${ }^{31}$ Postwar, the ambiguity of faith had both religious and political associations. Peter Hennessy cautiously confirms 'the decline in

${ }^{28}$ Blake planned to 'divide Westminster Hall, or the walls of any other great Building, into compartments and ornament them with Frescos' of religious scenes. Cf. Geoffrey Keynes, 'Introduction' in The Tempura Paintings of William Blake: A Critical Catalogue with an Introduction by Geoffrey Keynes (London: Arts Council of Great Britain, 1951), p. 5.

${ }^{29}$ John Bratby, 1980 conversation with J. H. Hamilton, Keeper, Sheffield City Art Galleries, quoted in Maurice Yacowar, The Great Bratby (London: Middlesex University Press, 2008), p. 20.

${ }^{30}$ Susan Matthews, “'And Did Those Feet?": Blake and the Role of the Artist in Post-War Britain' in Steve Clark (ed.), Tristanne Connolly and Jason Whittaker (eds), Blake 2.0: William Blake in Twentieth-Century Art, Music and Culture (Houndmills: Palgrave Macmillan, 2012), p. 152.

${ }^{31}$ Cary, The Horse's Mouth, p. 28. 
active religious practice if not belief itself', noting 'the social arithmetic of belief' to be 'one of the most vexing areas' for a historian. ${ }^{32}$ More reliable than records of churchgoing are the figures for political membership: though the Soviet response to the Hungarian uprising in 1956 proved an ideological turning point for so many, as early as 1949 Arthur Koestler was meaningfully able to pronounce Communism to be 'The God that Failed. 33

Yet a faith in the regeneration of Britain had to be maintained, and this was one in which art played, as Matthews points out, a vital role. Postwar, she claims, 'art threatens to take over from religion as a means of regulating order and cultural value'.34 Nowhere is this more apparent than in one of the iconic sites of rebuilt Britain. When his design for Coventry Cathedral was chosen in 1951, Basil Spence immediately set about securing his building's largest works of art. As Elain Harwood points out: 'By commissioning the artworks early, Spence ensured they could not be eliminated as budgets became squeezed.'35 In fact, the design of the cathedral itself was recast in 1955 when it became evident that the cost of the original superstructure, in addition to the art commissions, would exceed available funds.

In the midst of the Second World War, Jimson is already sensible of the need for such triumphant national statements of public art. While negotiating the sponsorship of his next mural, he notes, 'A work this size is not suitable to a public gallery. It really needs a cathedral ... [S] uch a building, thoroughly modern in style, would really be

32 Peter Hennessy, Having It So Good: Britain in the Fifties (London: Allen Lane, 2006), p. 123.

33 Arthur Koestler (ed.), The God that Failed: Six Studies in Communism (New

York: Harper \& Brothers, 1949).

34 Matthews, 'And Did Those Feet?' p. 152.

35 Elain Harwood, England: A Guide to Post-War Listed Buildings (London: Batsford \& English Heritage, 2003), p. 148. 
cheaper in the long run. Lighted by daylight bulbs. Open day and night.'36 Jimson prophesises the aesthetic of some of the most cherished of postwar churches, as well as the aspirations of gallery spaces much later in the century, and his design is predicated on more than a desire for free drinks to draw in the public (although that forms an important feature). Encapsulated in an ecstatic incantation of similes and metaphors, his lengthy exposition of his vision of postwar art melds a mix of media with the growth of spiritual communities: in conclusion, a picture, he tells his acolyte Nosy, 'is like a tree or a church, you've got to let it grow into a masterpiece. Same with a poem or a new religion' ${ }^{37}$ Art's role in restoring a communal sense of the sacred is more important to the postwar artist than denominational concerns. This was encapsulated in Spence's response to a committee shocked at his proposal of Jacob Epstein to sculpt St Michael, Coventry Cathedral's eponymous saint: 'There was a shocked silence, at length broken by the remark, "But he is a Jew," to which I replied quietly, "So was Jesus Christ"'.38 Cary's attempts to figure the postwar relationship between artistic representation, politics, spirituality and morality continued to his death in 1957 . The year before, he had given the Clark Lectures at Cambridge University under the title 'Art and Reality'. Here, he revealed what he considered to be the 'all-important truth in the distinction between the arts' - that it is writing which has the potential more reliably to reveal both moral (abstract, personal, religious) and ethical (communal, political) truths: 'A novelist creates a world of action and therefore he has to deal with motive,

36 Cary, The Horse's Mouth, p. 346.

37 Ibid., p. 209.

38 Basil Spence, Phoenix at Coventry: The Building of a Cathedral (London: 
with morality. All novels are concerned from first to last with morality.'39 Thus, Cary maintained his faith in the ekphrastic novel as a vital means of exploring the moral priorities of artistic and spiritual rejuvenation in the wake of war.

\section{'Subject and Object and the Nature of Reality': Elizabeth Taylor's Ekphrasis}

Like Cary, Elizabeth Taylor was drawn to the figure of the painter in her fiction as a means of exploring the ethical imperatives of postwar society. In the letters to Ray Russell which, for the early part of her career, provide us with the most sustained exposition of her aesthetic practice, 'the abstract thinking was about both genres' ${ }^{40}$ Competing allegiances to modernism and realism are given play in her most dedicatedly ekphrastic novels. Her 1947 novel $A$ View of the Harbour regularly and radically invokes To the Lighthouse. In Woolf's novel, Lily Briscoe's incremental portrait of Mrs Ramsay ultimately becomes an object that, like the novel itself, is offered as the reconciliation of Mr Ramsay's fraught philosophical enquiry into 'subject and object and the nature of reality'. ${ }^{41}$ Lily's painting is the material means of encapsulating her shifting subjective response to her subject and her unifying artistic vision. In $A$ View of the Harbour, in Taylor's seaside town of Newby, Lily Wilson, widowed by the Second World War, seeks to defy further confrontation with that 'nature of reality' in her reading practices. Absorbed in a romance novel, 'she sank deeply as if under an anaesthetic,

39 Joyce Cary, Art and Reality: The Clark Lectures 1956 (Cambridge University

Press, 2013), p. 149.

40 Nicola Beauman, The Other Elizabeth Taylor (London: Persephone Books, 2009), p. 201.

41 Virginia Woolf, To the Lighthouse (Harmondsworth: Penguin, 1972), p. 28. 
away from empty and makeshift reality; she went down willingly and pleasurably, relinquishing with eagerness the gritty irritations of the Harbour streets, the smell of fish, the dusty shops with their cast-off clothes and furniture'.42 In drawing upon the aesthetics of romance, modernism and realism, Taylor uses the novel to explore their competing claims of representation, and undermines established cultural hierarchies in the process.

'Think of a kitchen table ... when you're not there', suggests a sanguine Ramsay child as a means of summarising his father's life's work to Lily Briscoe. ${ }^{43}$ At the kitchen table in another of Taylor's harbour cottages, Beth Cazabon, subject to the demands of maternal and marital chores, is writing yet another novel. Beth's writing is never shown to Taylor's reader, but her leading lady's name ('Allegra'), and the select glimpses afforded of the melodramatic incidents that befall her, bode precisely the kind of romantic fiction that Lily Wilson craves. ${ }^{44}$ Beth considers objectivity to be anathema to creativity - as a result, Taylor suggests, she is unable to detect the affair between her husband and their neighbour Tory Foyle. As Tory puts it: 'Writers are ruined people. As a person, you're done for. Everywhere you go, all you see and do, you are working up into something unreal, something to go on paper.'45

Desperate to escape the guilt of betraying her friend, Tory agrees to marry the harbour's out-of-season visitor Bertram Hemingway. He is in Newby to paint, although in fact (Taylor notes tartly), he 'was not much of an artist, in spite of having found a very

42 Elizabeth Taylor, $A$ View of the Harbour (Harmondsworth: Penguin, 1954), p.

29.

43 Woolf, To the Lighthouse, p. 28.

44 Taylor, $A$ View of the Harbour, p. 256.

45 Ibid., p. 63. 
good way of painting waves with tops folding over whitely, realistically'.46 Although produced over the few weeks of the novel's diegesis, Taylor's acerbic humour works to make Bertram's work-in-progress seem almost as attritional as Lily Briscoe's. Unlike Taylor's, the mixed nature of Bertram's stylistic allegiances is detrimental to his artistic production. He toys with the idea of gaining access to the commanding position of the lamp-room of the lighthouse to paint that eponymous view of the harbour. However, his reflex response to the tower is one of quotidian realism rather than symbolism: 'in his mind's eye, his painter's eye, he saw the two men sitting in the little building which crouched in the shadow of the tower; there they were, in shirt-sleeves, fans of greasy cards in their hands, ${ }^{47}$ Bertram oscillates between that realist impulse and a romantic belief in the illuminating light of artistic genius. After a long pause while she contemplates his finished painting, intended to inspire public awe in the harbour-side pub, Tory responds, “'It is very good. Very like. There is only one thing ... it is quite obvious where it is, but not what time of day ..." Bertram said sadly: 'In fact the very thing I most hoped to do I have failed over"'.48 Oscillating between harsh daylight and the dramatic, selective beam of the lighthouse, the light in the painting is all wrong.

W. J. T. Mitchell notes an enduring cultural ambivalence about ekphrasis as a possible and desirable practice, claiming this suspicion is grounded 'in our ambivalence about other people, regarded as subjects and objects in the field of verbal and visual representation'. ${ }^{49}$ This might call us back to To the Lighthouse ('subject and object and the nature of reality'), but its focus is on the interpersonal nature of ekphrasis and the

46 Ibid., p. 6.

47 Ibid., p. 112.

48 Ibid., p. 247.

49 W. J. T. Mitchell, 'Ekphrasis and the Other' in Picture Theory: Essays on Verbal and Visual Representation (Chicago, IL and London: University of Chicago Press, 1994), p. 163. 
fact that it is inescapably an ideological gambit. 50 What Heffernan defined as 'the verbal representation of visual representation' is a nexus for both moral and ethical issues. 51 The politics of Taylor's work, like that of much fiction deemed middlebrow, have been overlooked. That epistolary exploration of thinking between the genres of painting and writing with Ray Russell (himself a painter) took place between two working members of the Communist Party. Postwar, Taylor, like all her comrades, had to come to terms with a creeping loss of faith in the Soviet Union as exemplar. The politics of her fiction are inarguably domestic rather than international. Yet her mixing of genres, legible as a rebellion against a cultural hierarchy that branded her work as unimportant, can also be understood to defy what David Carroll identifies as 'the totalized, organic unity of the artwork as both an aesthetic and political ideal'.52 This is Carroll's definition of the founding principle of fascist art, but after the Hungarian Revolution of 1956, we can appreciate its uncomfortable implications for those on the Left as well.

Taylor's negotiation of ethical living and artistic creation continues in the 1957 novel Angel. The novel's diegesis runs from 1885 to 1947 , and it is the story of a grocer's daughter, Angelica Deverell, whose fevered adolescent novel The Lady Irania begins a lucrative, if critically derided, career in romance writing. Her fortune made, and mindful of her civic duty as an 'artist', she donates a large work by Victorian painter George Frederick Watts to Norley Art Gallery. Her selection is made on the advice of the traditionalist Lord Norley himself, in whose circles her wealth now allows her to move.

50 Woolf, To the Lighthouse, p. 28.

51 James A. W. Heffernan, Museum of Words: The Poetics of Ekphrasis from Homer to Ashbery (University of Chicago Press, 1993), p. 7.

52 David Carroll, French Literary Fascism: Nationalism, Anti-Semitism, the Ideology of Culture (Princeton, NJ and Chichester: Princeton University Press, 1995), p. 7. 
Norley introduces her to his nephew, the man who, by means of attrition rather than passion, she will marry.

Esmé Howe-Nevinson is himself a painter, in a mode that is staunchly antithetical to the genteel classicism of Watts, and contemporary to the novel's publication rather than its setting. His paintings depict '[b]armaids and jockeys, barges in the fog, back-streets in the pouring rain, slag heaps ... the seamy side of life'. 'Don't forget the allotments, Uncle', Esmé's sister adds spitefully, 'with all the horrid little toolsheds and rubbish-heaps'. 'And cemeteries', Esmé adds cheerfully. 'I am particularly fond of my cemeteries.'53 Esmé's self-esteem as an artist is founded upon a faith in the authenticity of his depictions of working-class urban landscapes and interiors: 'those subfusc bars, with their ferns and patterned glass, marble-topped tables, immense hatstands' ${ }^{54}$ This sets him apart, he believes, from the fantastical nature of his wife's romance. Broken by his experience of war and his betrayal of his wife, Esmé kills himself, leaving Angel increasingly to alienate her readership as she attempts to produce realist narratives that confront conflict, rather than offering escape from it.

Just as $A$ View of the Harbour reflects, rewrites and interrogates To the Lighthouse, so Angelis intertextually entwined with Woolf's 1934 essay 'Walter Sickert: A Conversation'. Sickert, who died in 1942, remained a significant influence on English culture in the later 1940s and 1950s. At the Royal College of Art, as well as other major schools, Maurice Yacowar has claimed, 'Sickert was in the air'. 55 Postwar, Sickert's art and writing were widely disseminated, along with a new biography and a critical study. There was a large Arts Council exhibition in 1949, as well as several one-man shows in

53 Elizabeth Taylor, Angel(London: Virago, 2001), p. 89.

54 Ibid., p. 136.

55 Yacowar, The Great Bratby, p. 19. 
commercial galleries and numerous appearances in group exhibitions. In Woolf's interwar essay, a dinner guest claims they 'once read a letter from Walter Sickert in which he said, "I have always been a literary painter, thank goodness, like all the decent painters"'.56 Years after Esmé's death, Angel is delighted when a young academic, Clive Fennelly, visits to research an article on the painter: 'She took his essay to the window, straining her eyes to read it. "A literary painter," she said. "I like that very much. That would have pleased Esmé". It seemed to her to be praise indeed; but Clive looked away, blushing' ${ }^{57}$ Fennelly is embarrassed because that 'literary' is intended as derogatory: by 1962, The Oxford English Dictionary is able to claim of a usage in a dictionary of art that the term is 'frequently used in a pejorative sense'. Taylor uses this meeting to force the instructive reassessment of Esmé's work in relation to Angel's, in its implication that Esmé's allegedly 'realist' paintings are as much an exercise in romanticising reality as his wife's novels. Taylor's perception of the ideological nature of art is acute, and often self-coruscating. Her allegiance to the anti-realism of interwar modernism (and her own tendency to disrupt her narratives with modernist ellipses) is offset in the novel by her celebration of the empathetic power generated by the graphic representation of Angel's return to poverty. Like Cary, Taylor upholds the need for the postwar artist constantly to critique the ethics of the aesthetics to which they pledge allegiance.

${ }^{56}$ Virginia Woolf, 'Walter Sickert: A Conversation' in The Death of the Moth (London: Hogarth, 1947 [1934]), p. 26.

57 Taylor, Angel, p. 240. 


\section{'Between Red and Blue': John Berger and Modernist Realism}

In her descriptions of Esmé's work and its dilapidated urban landscapes, Taylor presents an inventory of approved subject matter for the developing movement towards social realism in 1950s art. John Berger approvingly noted in the $\mathrm{NeW}$ Statesman in 1951 that artists like John Bratby, Derrick Greaves and Jack Smith had a particular 'way of looking at the back garden, the railways, the wharf, the street, the herring fisheries, the deck-chairs on the pier'.58 Yet fellow critic David Sylvester claimed in 1954 that: 'Most of the painting produced by the present vaunted revival of realism has ... been romantic painting'.59 'How many fictions', he went on to ask, 'are made in the name of "realism" which are simply representations of squalor treated in a highly stylized manner?'60 Sylvester was a powerful champion of a realist art that, while still clearly figurative, is derived from a reading of late modernism and prizes allusion, emotion and phenomenological experience above illustration and narrative. In a 1951 lecture at the Royal College of Art, Sylvester defined reality as 'the series of sensations and ideas that occur in the consciousness of each individual': a notably modernist interpretation. 61 His criticism upheld Francis Bacon and Lucien Freud as exemplary exponents of this notion of realist practice.

58 John Berger, 'Treasure Trove', New Statesman, vol. 42, no. 1069 (1 September 1951), pp. 226-7.

${ }^{59}$ David Sylvester, 'Round the London Galleries', Listener, vol. 51, no. 1303 (18 February 1954), p. 304.

60 David Sylvester, 'Response to Barlow', Listener(18 March 1954), p. 485.

61 David Sylvester, About Modern Art: Critical Essays 1948-96 (London: Chatto \& Windus, 1996), p. 17. 
It was Sylvester who, in 1956, identified '[o]ne of the odder intellectual conflicts of the present time', which he dubbed the 'battle for realism'. Identifying the battle as a form of 'psychological warfare, waged by propagandists', his role in this conflict was not as detached as his tone might suggest. ${ }^{62}$ Resident critic at the anti-Stalinist Encounter, Sylvester's art criticism and curatorship have been uncompromisingly characterised by Juliet Steyn as attempts to sever class consciousness from realist pictorial art. In this heavily ideological gambit, she claims, art criticism produced 'a version of the postwar consensus in which ideological differences, class divisions and structural inequalities were being apparently eroded'.63 In July 1952 at the ICA in London, Sylvester co-curated the exhibition Recent Trends in Realist Painting. The exhibition made an eclectic grouping, including work by Bacon, Bernard Buffet, Freud, Alberto Giacommetti and Graham Sutherland. This, the introduction to its catalogue claimed, should be considered 'a cross section, inevitably arbitrary ... of what has been done in recent years by painters who have been prepared to face up to appearances'.64 Its understanding of 'realist painting', then, inflected realism as a fundamentally individualistic, rather than communal, project, and this was borne out in its hanging of a marked preponderance of portraits and single figures.

James Hyman has called the defining style of Sylvester's championed artists 'modernist realism'. 65 Although this term jolts an exclusively literary critic, it does suggest a productive means of analysing Elizabeth Taylor's own highly ambivalent relationship with literary narrative as a means both of driving and interrupting her

62 Sylvester, 'Round the London Galleries', p. 896.

63 Juliet Steyn, 'Realism versus Realism in British Art of the 1950s', Third Text: A Very Special British Issue, vol. 22, no. 2 (2008), p. 152.

64 Quoted in ibid., p. 152.

65 Hyman, The Battle for Realism. 
observation of real life. 'Neither art itself nor life itself', Woolf called the middlebrow. ${ }^{66}$ Taylor's ultimate withdrawal of authenticity from Esmé's work by wielding the very word, 'literary', that has such value for Woolf, suggests not just an ongoing critique of her own middlebrow status, but a wider dissatisfaction with the drawing of the postwar battle lines between modernism and realism.

In September 1952, a mere two months after Sylvester's Recent Trends in Realist Painting, the exhibition Looking Forward at the Whitechapel Gallery in London offered a very different perspective on realist art. Tending towards the prosaic subject matter favoured by Esmé, its focus was upon communal and domestic settings. John Berger, its curator, and a painter and writer himself, was the critic Sylvester was to have in his sights when he later wrote of the 'propagandists' of the 'battle for realism'. 67 Berger's exhibition was engaged in framing an English realist tradition to authenticate and support the work of painters like Bratby and Smith. '[J]ust as their comparatively representational pictures imply an acceptance of revolutionary theories of the last forty years', he wrote in the New Statesman, 'their way of looking at the back garden ... implies a fresh intention'.68

The work (and writings) of Walter Sickert formed a crucial pillar of the exhibition's ideological construction. 'The more our art is serious', Sickert had pronounced in 1910, 'the more will it tend to avoid the drawing-room and stick to the kitchen'.69 Ironically, it was Sylvester who coined the enduring name for Berger's vaunted group of artists, in a 1954 article that denounced their aesthetic inventory (and

66 Woolf, 'Middlebrow', p. 113.

67 Sylvester, 'Round the London Galleries', p. 896.

68 John Berger, 'Treasure Trove', New Statesman, vol. 42, no. 1069 (1 September 1951), pp. 226-7.

${ }^{69}$ W. R. Sickert, 'Idealism', Art News (12 May 1910), p. 217. 
philosophy) as he named it. Their paintings, he claimed, were full of 'every kind of food and drink, every kind of utensil and implement, the usual plain furniture, and even the baby's nappies on the line. Everything but the kitchen sink? The kitchen sink too'.70 Berger's introduction to the catalogue of Looking Forward adopted what might appear as a straightforwardly anti-modernist stance: 'The aim is to show the work of painters who draw their inspiration from a comparatively objective study of the actual world ... who are concerned with the reality of that subject rather than with the "reality" of their subjective feelings about it'.71

Through a sequence of articles across the decade, Berger orchestrated an attack on the artist Sylvester considered to be 'the most important living painter', Francis Bacon.72 Bacon was, Berger claimed, 'a brilliant stage manager, rather than an original visual artist', and the emotion generated by his paintings, although undeniably haunting, is 'concentratedly and desperately private'. In the nub of Berger's critique, Bacon was left 'really outside the main tradition'.73 But that marginally exclusionary tradition is still, importantly, one of English realism. However much he may reject Bacon on the grounds of an intrusive modernist solipsism, Berger recognised him as a practising realist, albeit one at fundamental odds with Berger's own ethical conception of that practice. Back in 1936, Walter Benjamin had rejected the concept of genius in art for its

70 David Sylvester, 'The Kitchen Sink', Encounter, vol. 3, no. 6 (December 1954), p. 62 .

71 John Berger, 'Foreword' in Looking Forward (London: Whitechapel Art Gallery, 1952), quoted in Hyman, The Battle for Realism, p. 118.

72 David Sylvester, 'The Paintings of Francis Bacon', Listener (3 January 1952), p. 29.

${ }^{73}$ John Berger, 'Francis Bacon', New Statesman and Nation (5 January 1952), p. 11. 
potential affiliations with fascism.74 In postwar Britain, although political principles of community and individuality rage on, their simplistic divide into realist and modernist in extremis, into communist and fascist - can no longer be sustained.

Berger's own painting career had halted by the time of the 1958 publication of his first novel, $A$ Painter of Our Time. Its protagonist, Hungarian émigré Janos Lavin, is tormented by an era which valorises its artists as genius outsiders: 'Again I hear the sceptic's questioning encouraged by the amoral limbo in which we live, and where any attempt to connect art with social responsibility and morality is immediately ridiculed by parody.'75 The first of Lavin's paintings described in the novel is called 'The Waves', a title shared by Virginia Woolf's most experimental (most modernist) novel. In Hungary, Laszlo, Lavin's old friend, is making speeches about Socialist Realism arousing the consciousness of the working classes: 'What would he think of my Waves', worries Lavin, 'moving past like clouds over mountains?'76 The serenity - of content and of palette - is read as antithetical to Laszlo's political engagement. 'There is no red in The Waves,' Lavin reluctantly recognises, 'I must wait for another canvas'.77 His subsequent paintings worry, with increasing success, at techniques that combine subject, content, colour and form to produce authentic expression. Painting an individual portrait, Lavin asserts: 'Colour and form must make the expression of the character. The expression on the face is only a sign - like a weathercock. All temperament can lie between red and blue. ${ }^{78}$ Traditional conceptions of political allegiance are, of course, coloured in the same contrasting way.

\footnotetext{
${ }^{74}$ Walter Benjamin, The Work of Art in the Age of Mechanical Reproduction (Harmondsworth: Penguin 2008), p. 2.

${ }^{75}$ John Berger, A Painter of Our Time (London: Verso, 2010), p. 153.

76 Ibid., p. 50.

77 Ibid., p. 21.

78 Ibid., p. 101.
} 
In 1960, in Permanent Red: Essays in Seeing, Berger registered the ongoing effects of the schism caused within Leftist thought by the Hungarian Uprising of 1956. As he was later to put it, with striking simplicity, 'the USSR represented ... a great part of the force of socialist challenge to capitalism. It no longer does'.79 The cover image for the 1951 Looking Forward exhibition catalogue - a rural British worker, rake in hand, gazing into the future - is early evidence of the difficulty of Berger's task of distinguishing social realism from Socialist Realism as the decade progressed.

The literary form of $A$ Painter of Our Time - a diary enclosed within a firstperson account - is ungainly. The novel's attempt to process raw, recent history into art is obviously incomplete. Once again, this alerts us to the impossibility of representing the complex cultural and political environment of postwar Britain in a traditional realist mode (as well, of course, of the difficulty of constructing recent history as sequential literary narrative). Yet nonetheless the novel is able clearly to communicate its commitment to thinking across disciplines (writing, painting) as well as aesthetic categories (realism, modernism). In its most evocative metaphor, Lavin describes the process of cross-hatching:

You have the first series of lines, then you have the second series in opposition to the first. But out of the two you get a series of diamonds.

Now, if you look at these diamonds, remembering that every one has had to be drawn, you are overwhelmed by the length and complexity of the task. The diamonds are like the future we work for. Yet, courage. The first series of lines is there. All we have to do is cross them. 80 1985), p. 8.

${ }^{80}$ Berger, A Painter of Our Time, p. 43. 
In part, of course, this is a representation of the theoretical foundation of Marxism, dialectical materialism. Yet the image of the diamonds - their geometric beauty as well as their natural rarity - upholds Berger's conviction that the regeneration of society can be achieved by aesthetic means. His first novel, like Lavin's painting, attempts a form that defies the constrictive, and highly politicised, categories of realism and modernism. This practice reached its height in 1972 with $G$ and its multi-modal rendering of human political, psychological and sensory experience. Berger was then to recognise that 'everything I have written has been no more than a preparation for . . G.' ${ }^{81}$

After the Second World War, British culture demanded a new set of aesthetic and ethical practices. These were required to participate fully in the national aspiration towards a politics predicated upon the democratic distribution of wealth and opportunity, but they nonetheless had an increasingly fraught relationship with socialism. Art in all its forms was given an unprecedented role in the rebuilding of Britain: indeed, its communal apportioning was enshrined in the financial structure of welfare provision itself. Under established political models, traditional realist practice would seem the way forward, and the period's reputation as one dominated by dogmatic realism, in its fiction in particular, still endures. However, the turbulent politics of the Cold War, as well as the enduring influence of interwar modernism, ensured that postwar realism was under intense and disaffected scrutiny.

This chapter has examined the use of the figure of the painter in selected fiction as a means through which novelists confronted the postwar loss of faith in a range of established certainties: political, spiritual and aesthetic. Visual art, with its distinct critical vocabulary, aesthetic genealogies and politicised assumptions, has, as Cary,

81 James Vinson, Contemporary Novelists (London: St James Press, 1976), p. 129. 
Taylor and Berger all recognised, the potential to destabilise ossified literary practice in potentially productive ways. One of these traditional forms is the traditional Künstlerroman, the 'artist's novel': none of the novels considered here presents a narrative of formation. Rather, their emphasis is on disintegration, as Jimson ends in committing murder, Hemingway in resigned (if comic) failure and Howe-Nevinson in suicide. Lavin simply disappears. In its juxtaposition of diverse aesthetic practices and moral effects, ekphrastic fiction allows the exploration of a range of anxieties that themselves breach existing categorisations - be these red or blue, realist or modernist. As these fictional artists prove, this process is not without its casualties. 